Aurelia Journal
(Authentic Research of Global Fisheries Application Journal)
p-ISSN: 0000-0000
e-mail: aurelia.journal@gmail.com

\title{
PENGARUH PERBEDAAN KONSENTRASI GARAM TERHADAP KOMPOSISI PROKSIMAT PADA IKAN LOMEK (Harpodon neherus) ASIN KERING
}

\section{THE EFFECT OF DIFFERENT SALT CONCENTRATION ON PROXIMATE COMPOTITION IN DRY SALTED LOMEK (Harpodon nehereus)}

\author{
Putri Wening Ratrinia ${ }^{{ }^{*}}$, Aulia Azka ${ }^{1}$, Nirmala Efri Hasibuan ${ }^{1}$, Muh Suryono ${ }^{1}$ \\ ${ }^{1}$ Politeknik Kelautan dan Perikanan Dumai, Dumai, Indonesia \\ *Korespondensi: p.weningratrinia@gmail.com (PW Ratrinia) \\ Diterima 16 Agustus 2019 - Disetujui 14 September 2019
}

\begin{abstract}
ABSTRAK. Ikan lomek (Harpodon neherus) merupakan salah satu jenis ikan yang banyak dikonsumsi oleh masyarakat Riau dalam kondisi segar maupun diolah dengan penggaraman dan pengeringan. Permasalahan pada produk ikan lomek asin di pasaran adalah belum diketahuinya kadar proksimat, yang merupakan salah satu parameter penting dalam penentuan mutu produk perikanan. Tujuan dari penelitian ini adalah untuk mengetahui pengaruh konsentrasi garam terhadap kandungan proksimat pada ikan lomek asin. Penelitian dilakukan preparasi bahan baku dan pembuatan ikan asin menggunakan metode penggaraman kering dengan konsentrasi garam 5\%, 10\% dan 15\%. Penambahan konsentrasi garam 10\% merupakan perlakuan dengan hasil komposisi proksimat terbaik yaitu kadar air 15,4\%, kadar abu 23,66\%, kadar protein 50,64\%, kadar lemak 3,7\%, dan karbohidrat $6,6 \%$. Penambahan garam dengan konsentrasi yang berbeda berpengaruh terhadap komposisi proksimat ikan lomek asin kering, yang meliputi kadar air, kadar abu, kadar protein, kadar lemak, dan kadar karbohidrat.
\end{abstract}

KATA KUNCI: Ikan lomek; proksimat; penggaraman

ABSTRACT. Lomek fish (Harpodon neherus) is one type of fish that is consumed by Riau people in fresh condition or processed by salting and drying. The problem with salted lomek fish products on the market is the unknown of proximate levels, which is one of the important parameters in determining the quality of fishery products. The purpose of this study was to determine the effect of salt concentration on proximate content in salted lomek fish. The study was carried out the preparation of raw materials and the manufacture of salted fish using dry salting method with a salt concentration of $5 \%, 10 \%$ and $15 \%$. The addition of salt concentration of $10 \%$ is the treatment with the best proximate composition, namely $15.4 \%$ water content, $23.66 \%$ ash content, $50.64 \%$ protein content, $3.7 \%$ fat content, and $6.6 \%$ carbohydrate content. The addition of salt with different concentrations affects the proximate composition of dried salted lomek fish, which includes water content, ash content, protein content, fat content, and carbohydrate content.

KEYWORDS: Lomek fish; proximate content; salted fish

\section{Pendahuluan}

Provinsi Riau memiliki potensi produksi perikanan yang cukup besar, salah satunya pada subsektor perikanan tangkap. Menurut BPS Provinsi Riau (2015), potensi produksi perikanan di Riau yaitu sebesar 105.296,3 ton. Jenis ikan yang sering dikonsumsi masyarakat Riau adalah ikan lomek (Harpodon nehereus), dimana produksi ikan lomek pada tahun 2015 menurut BPS (2015) adalah sebesar 2021,1 ton. Masyarakat di Riau sering mengkonsumsi ikan lomek dalam bentuk segar dan diolah dengan cara pengeringan dan penggaraman. 
Permasalahan pada produk ikan lomek asin di pasaran adalah belum diketahuinya kadar proksimat. Dimana kita ketahui bahwa kadar proksimat merupakan salah satu parameter penting dalam penentuan mutu produk perikanan. Standar mutu ikan asin kering (SNI 8273:2016) antara lain: kadar air maksimum $40 \%$, dan kadar abu tidak larut asam 0,3\% (BSN, 2016). Penelitian terkait pengaruh konsentrasi garam terhadap kandungan proksimat ikan lomek asin kering belum pernah dilakukan. Beberapa parameter penting yang perlu dikaji terkait analisa proksimat adalah kadar air, kadar abu, kadar protein, kadar lemak, dan kadar karbohidrat.

Tujuan dari penelitian ini adalah untuk mengetahui pengaruh konsentrasi garam terhadap kandungan proksimat pada ikan lomek asin, sehingga diharapkan dapat meningkatkan penerimaan konsumen dan mutu ikan asin yang dihasilkan sesuai dengan SNI.

\section{Bahan dan Metode}

Bahan utama yang digunakan adalah ikan lomek (Harpodon nehereus) yang diperoleh dari Dumai, Provinsi Riau. Bahan kimia yang digunakan yaitu akuades, kjeltab jenis selenium, larutan $\mathrm{H}_{2} \mathrm{SO}_{4}$ pekat, $\mathrm{NaOH}, \mathrm{H}_{3} \mathrm{BO}_{3}$, larutan $\mathrm{HCl} 0.1 \mathrm{~N}, \mathrm{HCl} 6 \mathrm{~N}, \mathrm{H}_{3} \mathrm{BO}_{4} 2 \%$, buffer natrium karbonat, ethanol-ascorbic acid 0.1 $\%, \mathrm{KOH}$, larutan heksana, kapas bebas lemak, alumina aktif, natrium sulfat anhidrat $\left(\mathrm{Na}_{2} \mathrm{SO}_{4}\right)$ serbuk, alumina aktif, $\mathrm{SnCl} 2, \mathrm{HNO} 3$ pekat,MgNO3, lantannum $5 \%$.

Alat yang digunakan antara lain baskom, tampah, plastik box, nampan plastik, talenan, pisau, titimbangan analitik Sartonius tipe TE15025, cawan porselen, oven Yamato tipe DV-41, desikator (analisis kadar air); tabung reaksi, labu Erlenmeyer, tabung Sokhlet, pemanas Sibata tipe SB-6 (analisis kadar lemak); tabung Kjeldahl, destilator, buret (analisis kadar protein); tanur Yamato tipe FM 38 dan desikator (analisis kadar abu).

Penelitian ini diawali dengan pengujian organoleptik berdasarkan score sheet ikan segar. Kemudian ikan disiangi, dibuang isi perut, insang, dan sisik, kemudian tubuh ikan dibelah menjadi dua bagian (butterfly fillet) .Ikan yang telah disiangi dicuci dengan menggunakan air bersih mengalir. Ikan yang telah dicuci bersih ditiriskan di dalam keranjang plastik. Ikan disusun rapi dengan perut menghadap ke bawah agar tidak ada air di dalam rongga perut ikan. Setelah ikan ditiriskan, ikan ditimbang untuk mengetahui bobot ikan dan dapat menentukan konsentrasi garam yang akan ditambahkan. Selanjutnya ikan dijemur setelah disimpan selama penggaraman. Ikan lomek asin kering kemudian dilakukan analisis proksimat yaitu kadar air, kadar abu, kadar protein, kadar lemak, kadar karbohidrat (Gambar 1).

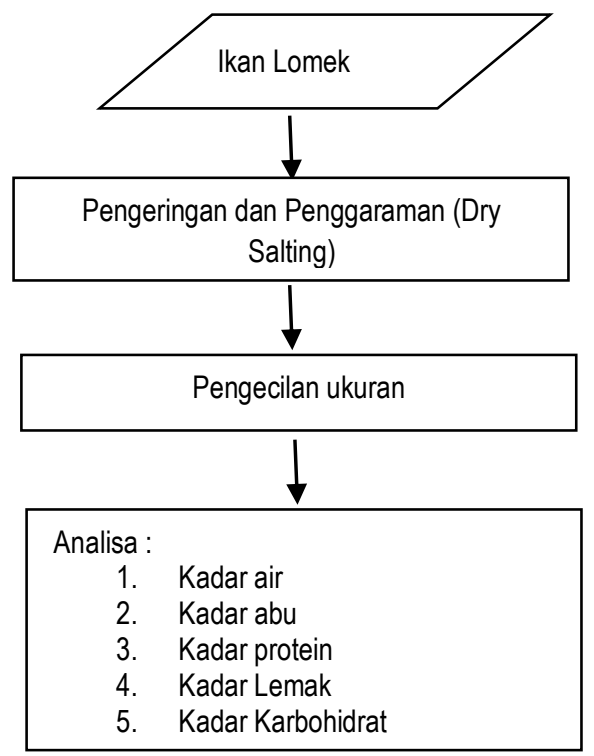

Gambar 1. Diagram Alir Prosedur Penelitian 
Pada penelitian utama dilakukan pengolahan ikan lomek asin kering berdasarkan perlakuan yaitu konsentrasi garam 5\%, 10\% dan 15\% dengan lama penggaraman dan lama pengeringan yaitu 24 jam. Dengan demikian dalam penelitian ini terdapat perlakuan seperti dalam Tabel 1.

Tabel 1. Perlakuan Penggaraman Ikan Lomek dengan Menggunakan Konsentrasi Garam yang Berbeda

\begin{tabular}{ccccc}
\hline Perlakuan & Kode & $\begin{array}{c}\text { Konsentrasi } \\
\text { Garam (\%) }\end{array}$ & $\begin{array}{c}\text { Lama } \\
\text { Penggaraman } \\
\text { (Jam) }\end{array}$ & $\begin{array}{c}\text { Lama } \\
\text { Pengeringan } \\
\text { (Jam) }\end{array}$ \\
\hline 1 & L1 & $5 \%$ & 24 & 24 \\
2 & L2 & $10 \%$ & 24 & 24 \\
3 & L3 & $15 \%$ & 24 & 24 \\
\hline
\end{tabular}

\section{Hasil dan Pembahasan}

\section{Kadar Air}

Kadar air merupakan air bebas yang hanya terikat secara fisik dalam jaringan matriks bahan seperti membran dan kapiler (Winarno, 2008). Kadar air ikan lomek asin kering berkisar antara 18,87 20,70\%. Gambar 2 menunjukkan bahwa kadar air yang paling tinggi terdapat pada perlakuan L1 yaitu dengan penambahan konsentrasi garam 5\%. Kadar air juga merupakan indikator yang baik untuk menentukan jumlah relatif energi, protein dan lemak ikan berkadar air rendah cenderung memiliki kadar lemak dan protein yang relatif tinggi (Dempson et al., 2004). Berdasarkan Gambar 2 dapat dilihat bahwa seluruh produk sudah memenuhi standar kadar air yang disyaratkan oleh Standar Nasional Indonesia (SNI) untuk mutu ikan asin kering. Kadar air untuk produk ikan asin yang ditetapkan dalam SNI (2016) adalah 40\%.

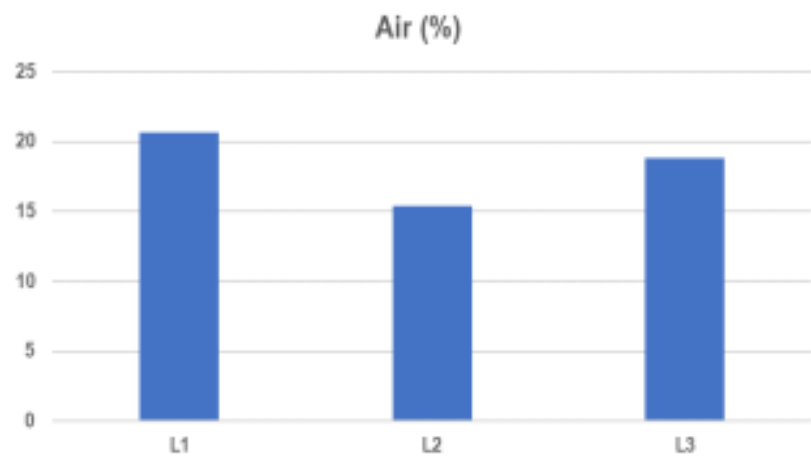

Gambar 2. Kadar Air Ikan Lomek (Harpodon nehereus) Asin Kering

Kadar Abu

Kadar abu merupakan campuran dari komponen bahan anorganik yang terdapat dalam ikan yang tidak terbakar dalam proses pembakaran bahan organic. Hal tersebut didukung oleh Winarno (2008) yang menyatakan bahwa kandungan bahan organik dan air di dalam bahan pangan mencapai $96 \%$, sedangkan sisanya sebanyak $4 \%$ merupakan unsur-unsur mineral (anorganik), kadar abu merupakan campuran dari komponen anorganik atau mineral yang terdapat dalam suatu bahan pangan yang tidak terbakar pada proses pembakaran bahan organik. Kadar abu pada penelitian ini adalah berkisar antara 22,45 \% - 24,43 \% (Gambar 3). Kadar abu tertinggi pada penelitian ini adalah pada perlakuan L1 yaitu ikan lomek dengan penambahan konsentrasi garam $5 \%$, sedangkan pada perlakuan dengan penambahan garam $15 \%$ memiliki kadar abu yang rendah. Hasil ini hampir sama dengan penelitian Ali et al., (2014) kadar abu ikan asin di daerah Lampung sebesar 25,8\%. 


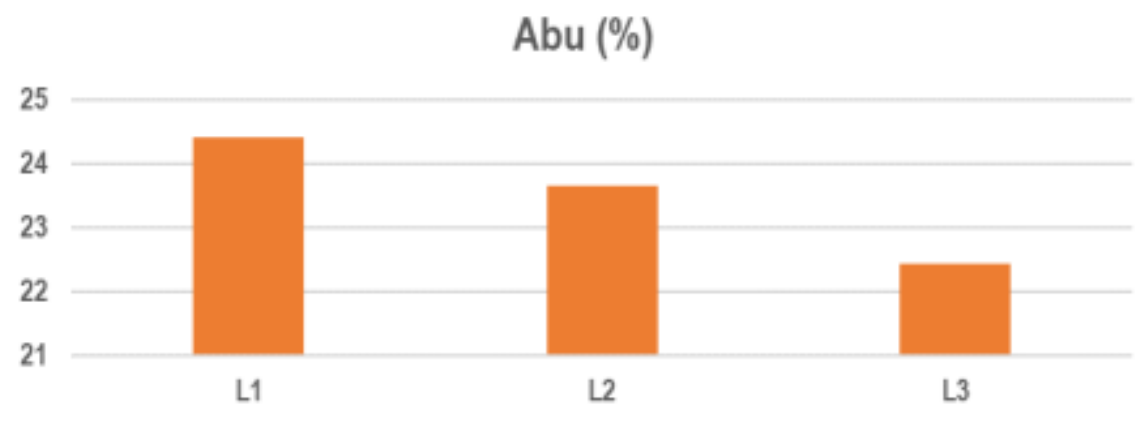

Gambar 3. Kadar Abu Ikan Lomek (Harpodon nehereus) Asin Kering

Kadar Protein

Hasil kadar protein pada penelitian ini adalah 46,33\% - 50,64\% (Gambar 4). Nilai kadar protein yang beragam pada sampel dikarenakan adanya perbedaan konsentrasi garam. Rahmani et al., (2007) menjelaskan bahwa perbedaan konsentrasi garam berpengaruh terhadap struktur protein. Selain itu, kadar protein akan meningkat ketika kadar air berkurang dalam suatu bahan pangan. Hal tersebut didukung oleh Adawyah (2007) dalam Riansyah et al. (2013), kadar air yang mengalami penurunan akan mengakibatkan kandungan protein didalam bahan mengalami peningkatan. Penggunaan panas dalam pengolahan bahan pangan dapat menurunkan persentase kadar air yang mengakibatkan persentase kadar protein meningkat. Selain itu, kadar protein juga berbeda pada masing-masing bagian tubuh ikan. Nakamura et al. (2007); Roy et al. (2010) melaporkan bahwa komposisi proksimat suatu ikan juga dipengaruhi oleh letak bagian tubuh pada ikan, bagian perut memiliki kandungan lemak lebih tinggi dan protein lebih rendah dibandingkan dengan bagian dorsal. Abraham-Olukayode et al. (2012) melaporkan bahwa semakin tinggi persentase proteinnya maka semakin baik ikan tersebut untuk dikonsumsi.

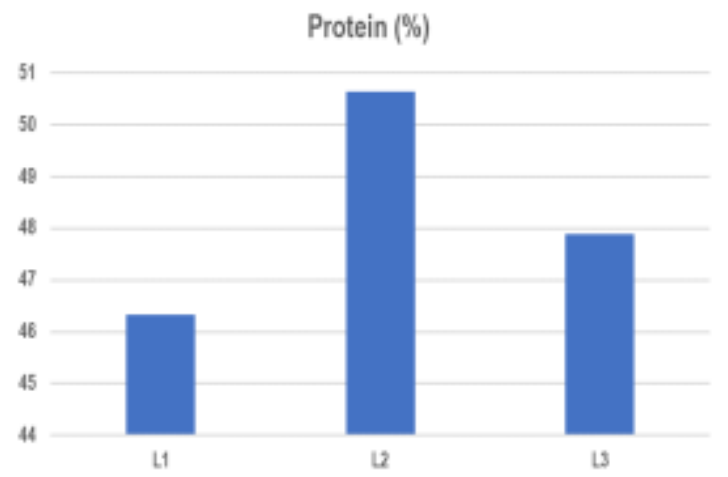

Gambar 4. Kadar Protein Ikan Lomek (Harpodon nehereus) Asin Kering

\section{Kadar Lemak}

Ikan lomek merupakan jenis ikan yang memiliki kadar lemak yang sedang. Hal tersebut dibuktikan pada hasil penelitian ini dimana kadar lemak pada ketiga perlakuan yaitu antara 3,24\% $3,72 \%$. Venugoval (2008) melaporkan bahwa ikan berlemak rendah memiliki kandungan lemak kurang dari $3 \%$, berlemak sedang memiliki kadar lemak 3-5\%, berlemak tinggi memiliki kadar lemak lebih dari $7 \%$. Perlakuan penambahan konsentrasi garam yang berbeda tidak berpengaruh terhadap kadar lemak secara signifikan. Pada Gambar 5, ditunjukkan bahwa kadar lemak yang paling rendah yaitu pada perlakuan penambahan garam $5 \%$, sedangkan yang paling tinggi yaitu pada penambahan garam $15 \%$. Hal tersebut berhubungan dengan hasil kadar air pada penelitian ini (Gambar 2), dimana pada perlakuan L1 memiliki kadar air yang paling tinggi, tetapi pada Gambar 5 menunjukkan bahwa kadar lemak pada perlakuan L1 adalah yang paling rendah. Menurut Hutuely et al. (1991) dalam Riansyah, 
(2013). Dengan mengurangi kadar air, bahan pangan akan mengandung senyawa-senyawa seperti protein, karbohidrat, lemak dan mineral dalam konsentrasi yang lebih tinggi, tetapi vitamin-vitamin dan zat warna pada umumnya akan berkurang.

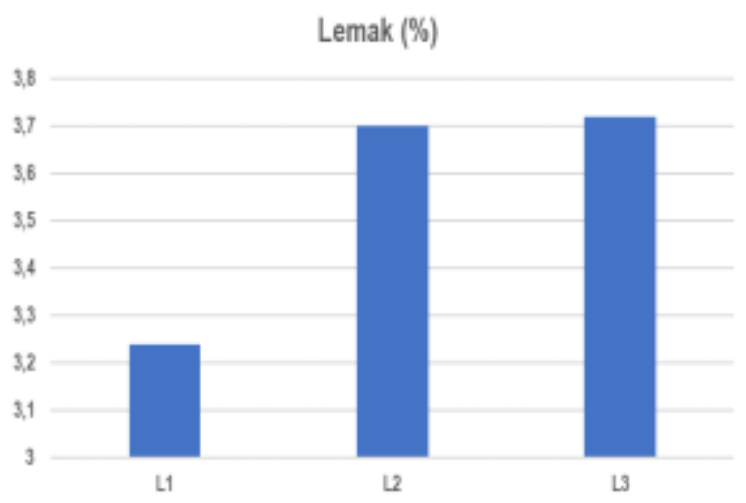

\section{Gambar 5. Kadar Lemak Ikan Lomek (Harpodon nehereus) Asin Kering}

\section{Kadar Karbohidrat}

Salah satu komposisi proksimat yang sangat dibutuhkan oleh tubuh manusia yakni karbohidrat sebagai penghasil kalori. Masing-masing jenis ikan memiliki kadar karbohidrat yang berbeda-beda. Perbedaan komposisi proksimat seperti karbohidrat dipengaruhi oleh dua faktor, yaitu faktor eksternal (eksogenus) dan internal (endogenus). Alemu et al. (2013) melaporkan bahwa faktor eksogenus utama yang mempengaruhi komposisi proksimat pada ikan adalah pakan, sedangkan faktor endogenusnya meliputi ukuran, umur, jenis kelamin dan tingkat kematangan gonad (TKG). Hasil penelitian pada parameter kadar karbohidrat adalah 5,3\%-7,06\% (Gambar 6). Kadar karbohidrat memiliki hubungan terbalik terhadap kadar air, yaitu semakin tinggi kadar karbohidrat semakin rendah kadar air pada suatu bahan pangan tersebut. Kadar karbohidrat ikan lomek asin kering tersebut lebih tinggi apabila dibandingkan pada ikan segar pada umumnya. Seperti pada penelitian Suhartini dan Hidayat (2005), kadar karbohidrat pada ikan yaitu berkisar 0-1,0\%.

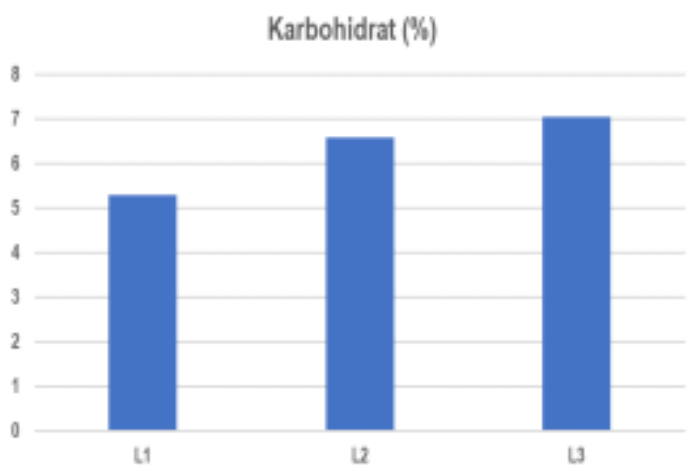

\section{Gambar 6. Kadar Karbohidrat Ikan Lomek (Harpodon nehereus) Asin Kering}

\section{Kesimpulan}

Penambahan garam dengan konsentrasi yang berbeda berpengaruh terhadap komposisi proksimat ikan lomek asin kering, yang meliputi kadar air, kadar abu, kadar protein, kadar lemak, dan kadar karbohidrat. Perlakuan L2 yaitu penambahan garam dengan konsentrasi 10\% merupakan perlakuan terbaik. Perlunya penelitian selanjutnya untuk mengetahui karakteristik mutu ikan asin kering yang sesuai dengan standard SNI. 


\section{Daftar Pustaka}

Abraham-Olukayode, AO Adejonuwo, OA Oramadike, \& CE Kolade, OY. (2012). Proximate Composition of $\mathrm{P}$. Elongatus Subjected to Different Processing Techniques. Journal Fish Aquatic Science. 8 (1): 282-286.

Alemu LA, Melese AY, \& Gulelat DH. (2013). Effect of Endogenous Factors on Proximate Composition of Nile Tilapia (Oreochromis niloticus L.) fillet from Lake Zeway. American Journal of Research Communication. 1 (11): 405-410.

Ali, M., Suparmono, \& S. Hudaidah. (2014). Evaluasi Kandungan Formalin pada Ikan Asin di Lampung. Aquasains. Jurnal IImu Perikanan dan Sumberdaya Perairan. 139-144.

[BPS] Badan Pusat Statistik. 2015. Produksi Nilai Perikanan Laut menurut Jenis 2014-2015. https://riau.bps.go.id

[BSN] Badan Standardisasi Nasional. 2016. SNI 8273:2016. Ikan Asin Kering. Jakarta (ID): Badan Standardisasi Nasional.

Nakamura YN, Ando M, Seoka M, Kawasaki KI, \& Tsukamasa Y. (2007). Changes of Proximate and Fatty Acid Compositions of The Dorsal and Ventral Ordinary Muscles of The Full-Cycle Cultured Pacific Bluefin Tuna Thunnus Orientalis with The Growth. Food Chemistry. 103: 234-24.

Riansyah. A., Supriadi. A., \& Nopianti. R., 2013. Pengaruh Perbedaan Suhu dan Waktu Pengeringan terhadap Karakteristik Ikan Asin Sepat Siam (Trichogaster pectoralis) dengan menggunakan Oven. Jurnal (on line), II (01), (http://www.thi.fp.usri.ac.id), diakses pada 20 Mei 2014.

Suhartini, S \& N. Hidayat. 2005. Olahan Ikan Segar. Surabaya: Trubusagrisarana.

Venugoval V. 2008. Seafood Processing; Adding Value Through Quick Freezing Retortable Packaging and Cook Chilling. New York (US): Taylor and Prancis publisher.

Winarno FG. 2008. Kimia Pangan dan Gizi. Jakarta (ID): Gramedia Pustaka Utama. 